\title{
National identities in the context of Shakespeare's Henry $V$ : Exploring contemporary understandings through collocations
}

\author{
Jonathan Culpeper and Alison Findlay \\ Lancaster University, UK
}

Corresponding author: Jonathan Culpeper, Department of Linguistics and English Language, Lancaster University, Lancaster, LA1 4YL, UK

Email: j.culpeper@lancaster.ac.uk

\begin{abstract}
Shakespeare's clearest use of dialect for sociolinguistic reasons can be found in the play Henry V, where we meet the Welshman Captain Fluellen, the Scotsman Captain Jamy, and the Irishman Captain Macmorris. But what might have contemporary audiences have made of these Celtic characters? What popular understandings of Celtic identities did Shakespeare's characters trigger? Recent technological developments, largely in the domain of corpus linguistics, have enabled us to construct robust but nuanced answers to such questions. In this paper, we use CQPweb, a corpus analysis tool developed by Andrew Hardie at Lancaster University, to explore Celtic identity terms in a corpus developed by the Encyclopedia of Shakespeare's Language Project. This corpus contains some 380 million words spanning the 80-year period 1560-1639, and allows us to tap into the attitudes and stereotypes that would have become entrenched in the years leading up to Henry V's appearance in 1599. We will show how the words tending to co-occur with the words Scots/Scottish, Irish and Welsh reveal contemporary understandings of these identities. Results flowing from the analyses of collocates include the fact that the Irish were considered wild and savage, but also that the word Irish had one particular positive use - when modifying the word rug. In discussing our findings, we will take note of critical discussions, both present-day and early modern, on 'nationhood' in relation to these characters and identities. We will also conduct, partly for contrastive purposes, a brief analysis of the English identity.
\end{abstract}

\section{Keywords}

collocations, English, Henry V, identity, Irish, nationality, Scots, Shakespeare, Welsh

\section{Introduction}

Today's audience hearing of a meeting between a Scots man, an Irish man, a Welshman and an Englishman may well be reminded of a type of joke, one in which stereotypes and prejudices about national identities are aired in the name of humour. In early modern England, as today, that humour, bound up with issues of ethnicity and race, betrayed anxieties based on a sense of threat. When William Shakespeare was writing the play Henry $V$, first performed in 1599 , England was caught up in a nine-year war to crush an Irish revolt - an issue that was dominating politics. Moreover, things had not been going well. In 1598, a year before the play was produced, the Irish leader Hugh O'Neill, Earl of Tyrone, had thoroughly routed English forces at the Battle of Yellow Ford on the Blackwater River in Ulster in August, and in October rebellion spread to Munster. The financial cost of the war to the English crown and people had been 
This is the final pre-publication version of: Culpeper, Jonathan and Findlay, Alison (2020) National identities in the context of Shakespeare's Henry V: Exploring contemporary understandings through collocations. Language and Literature 29(3): 203-222. It may contain minor errors or infelicities.

enormous, as Connolly (2007: 253) points out, with 33,000 English men levied for service between 1594 and 1601 and one account giving a total of 2,631 English killed and 1,158 wounded between 1593 and 1602, with half of the fatalities occurring at Yellow Ford. On 27 March1599, probably shortly before Shakespeare's play was produced, the Earl of Essex left for Ireland with an army of 16,000 foot in addition to 13,000 horse, the largest army ever to leave England (Hammer, 2008; Highley, 1997: 135). Shapiro (2006: 103) argues that the brevity of the performance run of Henry $V$ in 1599 and extensive cuts to the printed quarto texts Q1 (1600), including those to Essex and Ireland, were because of its focus on sensitive contemporary events (see Taylor, 1982:12). ${ }^{1}$ Against this backdrop, in Henry $V$ Shakespeare constructs four characters as military captains or officers, one from each 'nation': the English Gower, the Welsh Fluellen, the Scottish Jamy and the Irish McMorris. We will refer to the latter three as the Celtic characters. Ostensibly, all four characters are pursuing a common enemy, the French, the action of the play itself centring on the famous Battle of Agincourt, in which the English defeated a much larger French force. However, given the political backdrop, theatregoers would have known that any kind of 'United Kingdom' was more of a dream than a reality.

A key aim of this paper is to reveal in an empirical fashion how Shakespeare's contemporaries generally viewed the Scots, Welsh and Irish. Partly by way of contrast, we will also briefly pay some attention to the English. Literary characterisation, as cognitively-oriented models have made especially clear (e.g. Culpeper, 2001; Stockwell and Mahlberg, 2015), does not proceed in isolation from readers. Readers'

understandings of people or their social schemata, whether formed through direct exposure to people or though indirect (re)presentations (e.g. reports of people, fictional creations of them), play a major part in the construal of a character (see, for example, Culpeper, 2001: Chapter 2). The problem for historical literary texts is not simply that the language of the texts differs from today, but also that the minds of readers differ. By revealing the likely conceptions that Shakespeare's contemporaries had of the Scots, Welsh and Irish, we will better understand the nature and resonances of Shakespeare's characterisations.

We establish conceptions of 'nationalities' by investigating what people in the years around 1599 wrote about them, focussing on the uses and contexts of the words Scottish/Scots, Irish and Welsh, plus English. What is distinctive about our study is that it is based on frequency patterns on a grand scale, not on, for example, a few quotations that one scholar might select. We will adopt a key method from the world of corpus linguistics, namely, collocation analysis, a method that identifies the words that regularly co-occur with a particular word and thereby reveals its shades of meaning. This method is not dissimilar to the work by scholars who blend discourse analysis and corpus linguistics to investigate the representation of identities, an example being Baker et al.'s (2013) present-day work on Muslims and their representation in British newspapers. For our aim to succeed, we required a large corpus of language data, from which collocation patterns could emerge. The advent of Early English books Online (EEBO), and more specifically Early English Books Online-Text Creation Partnership (EEBO-TCP) provides the kind of size required. More specifically, we will be using a segment of EEBO-TCP specially curated for Shakespearean research by the Encyclopedia of Shakespeare's Language Project, the Enhanced Shakespearean Corpus: EEBO-TCP Segment (for further details regarding both the project and its resources, see the introduction to this special issue). 
This is the final pre-publication version of: Culpeper, Jonathan and Findlay, Alison (2020) National identities in the context of Shakespeare's Henry V: Exploring contemporary understandings through collocations. Language and Literature 29(3): 203-222. It may contain minor errors or infelicities.

In the next section, we will introduce some of the background to the play Henry $V$, giving a sense of what both literary scholars and historical linguists have said about Celtic characters. We will then provide some more detail on our data and method. The core of our paper discusses the results of our collocation analyses, beginning with Scottish/Scots, then Irish, and finally Welsh. We will also briefly contrast them with results for English.

\section{Background}

\subsection{Literary}

Holderness's (1991) important article, which takes the words of the Irish character Captain MacMorris in Henry $V$ as the first part of its title ('What Ish my Nation? Shakespeare and National Identities'), characterized the culmination of a backlash against Victorian imperialist celebrations of Henry $V$ as a play about national unity. Simpson (1874), for example, as quoted in Edwards (1979: 74), had argued that the four captains symbolise 'the union of four nations under one crown, and their cooperation in enterprises of honour, no longer hindered by the touchiness of a separatist nationalism'. Gould (1919: 42-45) viewed the play as a satire and Rabkin (1977: 96) emphasised its intrinsic duality rather than unity, a structural feature that is probably linked to its textual history as Dutton (2018: 181) notes. Building on these dissenting voices, Dollimore and Sinfield (1985: 216) claimed that "Henry $V$ is only in one sense "about" national unity: its obsessive preoccupation is insurrection.' As cultural materialists, they emphasised that such subversions of authority could not easily be contained (Dollimore and Sinfield, 1985: 216). Holderness used Captain MacMorris's line, as represented in the title of his article, as a starting point for his research, observing Henry V's dramatization of a 'more pluralistic and multiple, more complex and contradictory national collective' (1991: 76), and seeing in Kenneth Branagh's film version of Henry $V$ 'social contradictions of divided culture and fragmented nationality' (1991: 77), exemplified by the Belfast-born Branagh himself.

The Irish captain of Holderness's title has been the focus of many subsequent readings of the play's national politics like those by Christopher Ivic, Andrew Murphy, Willy Maley and Michael Neill, although Lisa Hopkins and Vimala C. Pasupathi have paid attention to its Welsh and Scottish elements (see, for example, Hopkins, 2004; Ivic, 1999; Maley, 2007; Murphy 1996; Neill, 1994; Pasupathi, 2013). As O’Neill (2016: 253) points out, however, MacMorris's equivocal performance of a 'stage Irish type', and the questions he raises about national identity, have made him 'a fetishized figure for critics'. O'Neill's (2016) astute analysis of the play's critical history in Maley and Loughnane (2016) pays credit to Highley's (1997) finely nuanced historicist reading on which we will draw below, but O’Neill (2016: 256) simultaneously urges critics to move beyond the colonial context and its canonised authors in order to see how the Irish, Scots and Welsh are represented by others as 'the matter of Britain'. Our contribution takes up that challenge. It is very different from Baker, Palmer and Maley's 'MACMORRIS' digital-humanities project, ${ }^{2}$ which aims to map early cultural activity across Ireland 'in all languages' (Baker et al., 2018: 1). Instead, we use corpus linguistics to read a large body of early English printed texts to explore how Shakespeare's English-speaking contemporaries might have understood representations of national identities and 'the matter of Britain' in Henry $V$. 
This is the final pre-publication version of: Culpeper, Jonathan and Findlay, Alison (2020) National identities in the context of Shakespeare's Henry V: Exploring contemporary understandings through collocations. Language and Literature 29(3): 203-222. It may contain minor errors or infelicities.

\subsection{Linguistic}

The following extracts illustrate the talk of the Celtic characters.

Jamy: It sall be vary gud, gud feith, gud captains beath, and I sall quite you with gud leve, as I may pick occasion. That sall I, marry.

MacMorris: It is no time to discourse, so Chrish save me. The day is hot, and the weather and the wars and the King and the dukes. It is no time to discourse [...].

Fluellen: Captain MacMorris, I think, look you, there is not many of your nation -

MacMorris: Of my nation? What ish my nation? Ish a villain and a bastard and a knave and a rascal? What ish my nation? Who talks of my nation?

However, before discussing what the characters say, it is worth noting their names. Proper names not only refer to particular individuals, but have specific semantic associations, often relating to the 'bearer's age, intellectual competence, race, ethnicity, social class, and other attributes' (Kasof, 1993: 140), and of course nationality. They are resources that authors can use to construct their characters (cf. Culpeper, 2001: 229231). The name Fluellen clearly represents the typical Welsh name Llwellyn, but the initial consonant has been anglicised, the $\langle f>$ representing a typical English pronunciation of Welsh <ll>. This is, in fact, consistent with, as we will show, contemporary views of the Welsh as a people who have been anglicised at least to a degree. Jamy similarly represents a typical Scottish name, but note that it is the form derived from James plus the suffix -ie/-y. The Oxford English Dictionary states that the 'use of this suffix in pet forms of proper names is found in Scottish as early as 1400' ($y$-ie, suffix 6). The uses of Jamy/Jamie in early modern English, though few, tend to be laced with warm affection or sympathy (e.g. 'King Jamy, Iemmy, Iocky my joy Summoned our king, why did ye so To you [..]', Pithy pleasaunt and profitable works of maister Skelton [...], 1568). In the case of the character Jamy, it is difficult to know whether this signalled greater fondness and loyalty for the Scottish character or was in some way condescending. MacMorris's name may allude to something more specific than him being Irish, as it is a hybrid. MacMorris seems to have been a development of the Anglo-Norman name Fitzmaurice, whereby the Fitz- prefix has been exchanged for the Gaelic Mac-, presumably to make it more in tune with local norms (Shapiro, 2006: 109). MacMorris's hybrid name echoes his hybrid nationality and consequent dilemma: 'What ish my nation?'

Scholars studying Shakespeare's language at any length typically comment on the speech of the Celtic characters, because their speech is amongst Shakespeare's few distinctive uses of accent and dialect for sociolinguistic reasons (the speech reflects the speech communities to which the fictional speaker supposedly belongs, the other famous example is of Edgar in King Lear, who has some features associated with the Kentish accent). ${ }^{3}$ As Blake comments, 'there is a marked absence of cant, slang and dialect in all Shakespearean plays' (1983: 30). In appreciating that accent and dialect, we need to recollect that in the period within which Shakespeare was writing, English 
This is the final pre-publication version of: Culpeper, Jonathan and Findlay, Alison (2020) National identities in the context of Shakespeare's Henry V: Exploring contemporary understandings through collocations. Language and Literature 29(3): 203-222. It may contain minor errors or infelicities.

was far from standardized; it was the language of variation and variants. There is, however, evidence that some forms of speech were more positively valued than others. George Puttenham, the assumed author of The Arte of English Poesie (1589: 121), attached great social value to London-based speech, and famously advised the poet: 'ye shall therefore take the usuall speach of the court, and that of London and the shires lying about London within 1x. myles and not much above'. There is evidence in Shakespeare's plays consistent with Puttenham's advice. For example, in the following exchange from As You Like It, how 'fine' an accent is seems to depend on regional and social factors:

Orl. Your accent is something finer, then you could purchase in so remoued a dwelling.

Ros. I haue bin told so of many: but indeed, an olde religious Vnckle of mine taught me to speake, who was in his youth an inland man [...]

Remote region - that is, those far from the inland London and adjacent shires, those on the fringes - are associated with 'rougher' accents. Wales, Scotland and Ireland, are, of course, regions of the British Isles that are at the furthest remove. Those accents, then, attracted negative evaluations. Raphael Holinshed (1577: chapter 5, no page number) comments on Scottish English:

The Scottish englishe is much broader and lesse pleasaunt in vtterance, then ours, because that nation hath not hitherto indeuoured to bring the same to any perfit order, and yet it is such in maner, as Englishmen themselues doe speake, for the most part be|yonde the Trent, whether the aforesayde a|mendement of our language, hath not as yet very much extended it selfe.

The specific features of the text that represent accent and dialect in the Celtic characters include the following (some of these can also be seen in the extracts at the beginning of this section):

\section{Captain Fluellen}

- Pronunciation: unvoicing of initial /b/ and /v/, e.g. pig for 'big', falorous for 'valorous'

- Grammar: lack of subject-verb concord, e.g. if there is not better directions (III.ii.60)

- Vocabulary: Expression associated with Welsh speakers, look you

Captain Jamy

- Grammar: lack of auxiliary 'have' in I wad full fain heard some question (III.ii.112-3)

Captain Macmorris

- Pronunciation: use of / / / for /s/ or /z/ (e.g. Chrish for 'Christ', ish for 'is'),

- Grammar: unusual past participles, e.g. I would have blowed up the town (III.ii.85-60) 
This is the final pre-publication version of: Culpeper, Jonathan and Findlay, Alison (2020) National identities in the context of Shakespeare's Henry V: Exploring contemporary understandings through collocations. Language and Literature 29(3): 203-222. It may contain minor errors or infelicities.

Shakespeare, however, was not overly concerned with accurately producing a Welsh, Scottish or Irish dialect. Of the features given above, the grammatical ones in particular are not, as far as we know, peculiar to those dialects. However, all the features generally differ from the London dialects of that time. In other words, they would have struck the London audience as unusual, and provided comic potential, especially since they could be taken as prompts for the actors to ham up their speech and launch into 'stage dialect'. Moreover, the key point is that such features provided cues for the relevant social stereotypes that the audience had in their heads. This paper's goal is to uncover, in as much detail as possible, those contemporary social stereotypes.

\section{Data and method}

Early English Books Online, which purports to contain the bulk of English material printed between 1473 and 1700, offers the kind of size required for our collocation analyses. Counting words is a fraught business, but it might comprise something in the order of 1.2 billion words. However, not all of it is relevant to our study, as we wish to tap into attitudes that are contemporaneous with Shakespeare's play, Henry V. Consequently, we used the collection of corpora created by the Encyclopedia of Shakespeare's Language Project, namely, the Enhanced Shakespeare Corpus (ESC) (it is termed 'enhanced' because of its tagging/annotation) (see the Introductory chapter of this special issue for more detail). One component of this is the ESC: EEBO-TCP Segment. As the name suggests, it contains texts from Early English Books Online, specifically the transcriptions made available through the Text Creation Partnership, transcriptions which enable searches of the texts. The ESC: EEBO-TCP Segment was compiled as a broad corpus to assist in contextualising analyses of Shakespeare's plays. It comprises some 380 million words spanning the 80-year period 1560-1639, and has regularised spelling, part-of-speech tagging and genre categorisation (see Murphy 2019, for detail). More specifically, within the ESC: EEBO-TCP Segment, our analyses are based on texts produced within the period 1560 to 1599, thereby tapping into the attitudes and stereotypes that would have been entrenched in the years leading up to Henry V's appearance in 1599.

Whilst it is the case that The ESC: EEBO-TCP Segment has had its spelling regularised using a specially trained version of Variant Detector (VARD), ${ }^{4}$ a program developed by scholars at Lancaster University over more than 15 years and most significantly by Alistair Baron, it is not the case that this program is $100 \%$ reliable. Consequently, we made the decision to search, simultaneously, for all the spelling variants of our target items, allowing us greater control and transparency. Those spelling variants from the relevant period were extracted from the Oxford English Dictionary and are listed below in Table 1. The format of the lists reflects the search syntax needed by our computer program: vertical pipe marks separate the variants; the wildcard asterisks allow for morphological variation, and also, notably, the addition of man (as in, for example, Welshman); and the opening and closing round brackets determine that all these variants comprise one search.

\section{Table 1. Search strings for Scottish/Scots, Irish, Welsh and English}

\begin{tabular}{|l|l|l|l|}
\hline Scottish/Scots & $\begin{array}{l}\text { (skottysh*|scottish*|skottish*|scotish*|schotish*|scotesh*|scotisch*|s } \\
\text { cottesh*|scottisch*|scottysh*|shotish*|scottes*|scotes*|skottes*|schot } \\
\text { es*|schottes*|schoyttis*|scoitis*|scoittis*|scotes*|scotis*|scottes*|sco }\end{array}$ \\
\hline
\end{tabular}


This is the final pre-publication version of: Culpeper, Jonathan and Findlay, Alison (2020) National identities in the context of Shakespeare's Henry V: Exploring contemporary understandings through collocations. Language and Literature 29(3): 203-222. It may contain minor errors or infelicities.

\begin{tabular}{|l|l|}
\hline & $\begin{array}{l}\text { ttis*|scottys*|skotis*|skottes*|skottis*|scotts*|scots*|scoats*|skots*|s } \\
\text { kotts*) }\end{array}$ \\
\hline Irish & $\begin{array}{l}(\text { irish*|iresh*|yressh*|yrish*|ireish*|yerish*|irich*|iriesch*|iriesh*|iri } \\
\text { sch*|irrisch*|irysch*|iyrish*|yrisch*|yrish*|yrysch*|iersch*) }\end{array}$ \\
\hline Welsh & $\begin{array}{l}\text { (welsh*|walsh*|wealch*|welse*|vellchie*|welch*|welsch*|velsh*|wa } \\
\text { lyssh*walch*|vvelsh*|vvalsh*|vvealch*|vvelse*|vvelch*|vvelsch*|v } \\
\text { valyssh*|vvalch*) }\end{array}$ \\
\hline English & $\begin{array}{l}\text { (englis*|englysh*|inglish*|anglysh*|engglysh*|englush*|englyss*|en } \\
\text { glech*|ynglych*|ynglyss*|inglys*|anglis*|angllis*|einglis*|ingglesh* } \\
\text { lingleis*|ingleisch*|ingles*|inglich*|inglis*|ynglis*|ynglys*) }\end{array}$ \\
\hline
\end{tabular}

We used the powerful program CQPweb (see Hardie 2012) to perform the analyses. Our searches returned the frequencies displayed in Table 2. This Table also includes the minimum frequency settings we used for our collocation analyses, as described below.

Table 2. Celtic identity words and frequency in ESC: EEBO-TCP, 1560-1599

\begin{tabular}{|l|l|l|l|}
\hline & No. of occurrences & $\begin{array}{l}\text { No. of texts in which } \\
\text { they occur }\end{array}$ & Minimum frequency \\
\hline Scots/Scottish & 13,288 & 333 & 50 \\
\hline Irish & 2,061 & 169 & 10 \\
\hline Welsh & 1,904 & 121 & 8 \\
\hline English & 25,496 & 1,217 & 100 \\
\hline
\end{tabular}

The main technique from corpus linguistics that is used in this paper is collocation analysis. The principle behind the notion of collocation is that words are coloured by the company they keep (Firth, 1957). By studying the words that co-occur with a target word, we can reveal evidence of a word's meanings and do so on a robust empirical footing. Collocations are co-occurrence patterns, a habitual co-occurrence between a target word, a 'node' (such as the word Irish) and the words or 'collocates' that tend to co-occur with it within a particular span (for example, 3 words to the left and 3 words to the right). Statistics are used to identify those co-occurrence tendencies. This involves comparing (a) the number of times two words, the node and a collocate, are observed actually occurring together within a certain span with (b) the number of times they might be expected to occur together by chance within a certain span (given the number of times they each occur in a corpus of a certain size coupled with assumptions about random distribution). Our specific method for each target word was as follows:

(1) We extracted all collocates that (a) occurred more than the minimum frequencies specified in Table 1 (this reduces the possibility of idiosyncratic results), ${ }^{6}$ and (b) had a Log-likelihood value of no less than 19.72. Log-likelihood is a measure of how much evidence we have for a co-occurrence being significant.

(2) We removed all collocates that occurred in fewer than four texts, in order to remove the possibility that a limited number of texts could skew the results. We also removed: highly grammatical words (e.g. the, an, of), repeated spelling variants were combined (the more frequent variant was used to represent the collocate), punctuation (where it appeared as a collocate), ampersand, the 
This is the final pre-publication version of: Culpeper, Jonathan and Findlay, Alison (2020) National identities in the context of Shakespeare's Henry V: Exploring contemporary understandings through collocations. Language and Literature 29(3): 203-222. It may contain minor errors or infelicities.

occasional proper noun skewing results (e.g. John was a collocate for Welsh, but half relate to John Welsh) and clear errors (e.g. Page appeared as a collocate for Welsh, but relates to the actual pages of the work and is thus clearly an error).

(3) We ordered the results according to LogRatio. ${ }^{7}$ LogRatio is a measure of the effect size, that is, how big the difference is between the relative frequency of the collocate alongside the target word or node, and its relative frequency in the rest of the corpus.

\section{The collocates of Scottish/Scots}

The collocates of Scottish and Scots combined are (the numbers in brackets indicate the raw frequency of the collocate followed by its LogRatio value):

Pictes (1225/10.8), Malcolm (1288/7.34), chronicles (2780/7.24), Queene (7987/6.82), Frenchmen (5137/6.57), invade (4582/6.49), discomfited (2523/6.47), Englishmen (6867/6.27), Danes (5193/5.95), homage (4261/5.80), borders (4286/5.61), writers (14822/5.25), Irish (5312/5.22), aid (14137/5.15), nobility (13766/4.50), King (386345/4.38), perceiving (11114/4.30), nation (22656/4.19), Scots (13048/4.17), won (12469/4.09), horsemen (11915/3.99), history (20901/3.82), English (50622/3.80), army (58093/3.64), camp (20110/3.57), slain (44055/3.53), James (21297/3.34), William (25830/3.32), Alexander (21337/3.28), entered (26940/3.07), lords (56233/2.97), French (42300/2.87), kings (117108/2.57), battle (43865/2.55), against (336688/2.47), war (71059/2.45), England (70408/2.42), amongst (65801/2.33), Dauid (39790/2.30), number (84524/2.14), sent (108246/1.98), thousand (67948/1.94), hands (91756/1.93), peace (84727/1.83), men (494274/1.61), enemies (75243/1.59), diverse (79511/1.48), kingdom (85503/1.47), hundred (72416/1.44), received (74489/1.40), came (153499/1.39), sea (85518/1.38), side (82057/1.26), put (143979/1.07)

Looking at collocates in isolation does not tell one much. For example, slain is a collocate, but we do not know who was slain. Consequently, we scrutinised the contexts of each collocate by generating a concordance of each one (slain, in fact, almost always pertains to the Scots). We then manually grouped the collocates, as far as was possible, into the following thematic groups, ordered according to the number of collocates in them:

WAR: won, horsemen, army, camp, battle, war, number (overlaps with Conquest and submission below, as it sometimes refers to the number slain), thousand (usually in reference to army numbers, but sometimes the number slain), peace, side (usually in the phrase 'on the Scottish side')

Associated Groups: Pictes, Frenchmen, Englishmen, Danes, Irish, aid (used to describe groups aiding the Scots), English, French

SCOTTISH KINGS/QUEENS AND NOBILITY: Malcolm, Queene, nobility, King, James, William, Alexander, David

HostiLE: invade, discomfited, borders, entered (usually followed by England or a part of England), against, hands (usually something negative experienced by the English at the 'hands of the Scots'), enemies 
This is the final pre-publication version of: Culpeper, Jonathan and Findlay, Alison (2020) National identities in the context of Shakespeare's Henry V: Exploring contemporary understandings through collocations. Language and Literature 29(3): 203-222. It may contain minor errors or infelicities.

CONQUEST AND SUPPRESSION: homage (usually to an English King), slain, put (often in reference to the Scots being 'put to flight')

SCOTTISH HISTORIES: chronicles, writers, history

POLITICAL POWER: nation, kingdom

Whilst all these groups are distinguishable, some could, of course, be seen as subgroups of others. For example, the HOSTILE and CONQUEST AND SUPPRESSION groups could be seen as sub-groups of WAR.

It is noticeable that many of the collocate groups characterise relations between the English and the Scots negatively. The dominant spatial relationship between the two is of invasion (cf. the HOSTILE group) or expulsion (cf. the CONQUEST AND SUPPRESSION group), as though protecting or extending an exclusive national identity in spite of (or perhaps because of) geographical proximity. Henry $V$ succinctly pinpoints this feature and the attendant anxiety it generates. When an English invasion of France is proposed (following King Henry IV's advice to his son to 'busy giddy minds with foreign quarrels' and so avoid rebellion at home (2HIV 5.1)), Henry V immediately worries about that the Scot 'will make raid upon us' (1.2.139). It is not just 'pilfering borderers', those who are marginalised from the centre of power, but the state government and militia that he fears:

We do not mean the coursing snatchers only

But fear the main intendment of the Scot

Who hath been still a giddy neighbour to us.

For you shall read that my great-grandfather

Never unmasked his power unto France

But that the Scot on his unfurnished kingdom

Came pouring like the tide into a breach.

Such fears had a basis in the 'auld allyance' between France and Scotland that had been kept by successive kings James I, II, III, IV, V and renewed in 1566 with Mary Queen of Scots. ${ }^{8}$ Note that both Frenchmen and French are collocates in the ASSOCIATED GROUPS cluster. Christopher Ocland's history, The valiant actes and victorious battailes of the English nation (1585: unnumbered) recalled the consequences of the alliance when James IV (the same king that married Margaret Tudor to unite English and Scots royalty) had invaded England to thwart Henry VIII's invasion of France, and had to be driven out at the Battle of Flodden:

Meane time kyng Iames which then of Scottes the regall mace did beare,

And to confirme the league, till warres of Britaines ended were,

With Frankes in hand, .... ...had most deuoutly sworne: ...

Himselfe with flaming fire, and sword, against our bankes doth bend

And sixtie thousand souldiours hard, all armed, training fast

In absence of their Lord, the Britaine borders wide doth wast.

By 1599 such fears revived during the crisis in Ireland, since in addition to the Scottish mercenaries who were helping the Munster rebels, it was rumoured that the Scottish 
This is the final pre-publication version of: Culpeper, Jonathan and Findlay, Alison (2020) National identities in the context of Shakespeare's Henry V: Exploring contemporary understandings through collocations. Language and Literature 29(3): 203-222. It may contain minor errors or infelicities.

nobility and even King James VI were offering support to Tyrone and his allies (Highley, 1997:146). Henry $V$ may thus register an underlying uncertainty and anxiety about James VI of Scotland as a king-in-waiting. Would he be the lawful successor to Elizabeth's throne or invade her kingdom?

However, three groups of collocates of Scots/Scottish are not coloured solely by negative attitudes: SCOTTISH KINGS/QUEENS AND NOBILITY, SCOTTISH HISTORIES and POLITICAL POWER. Moreover, all groups are related to power. They generally reflect alliances between the two kingdoms through marriages such as that between Margaret Tudor (sister of Henry VIII) and James IV, whose grandson James VI would succeed Elizabeth I and bring a union of the crowns in 1603. These collocates register the Scots as a nationality group with a distinguished heritage, as established in historical records and symbolized by illustrious monarchs. In spite of the dynastic alliances between the kingdoms, the Scots thus posed a serious threat to the English. As Baker (2004: 33) has pointed out, Scotland threatens England because the marches, the borderland between the two kingdoms, is permeable, thus creating anxieties that the 'weasel Scot' could come 'pouring like the tide into a breach' (Henry V 1.2.150) at any time.

\section{The collocates of Irish}

The collocates of Irish are (the numbers in brackets indicate the raw frequency of the collocate followed by its LogRatio value):

rug (179/10.6), mere (984/8.23), Welsh (1434/7.80), Scots (13048/7.21), Irish (5312/6.78), Picts (2254/6.76), wild (17837/6.33), savage (4367/6.18), slue (3899/6.10), rebels (7193/6.08), Scottish (4397/5.93), seas (16018/5.51), Ireland (12297/5.31), aid (14137/4.95), nation (22656/4.86), English (50622/4.15), gentleman (19238/4.04), slain (44055/4.00), lords (56233/4.00), borne (50908/3.74), tongue (37141/3.39), wars (33107/2.88), enemies $(75243 / 2.83)$, thousand (67948/2.76), hundred (72416/2.59), certain (129291/2.40), men (494274/2.39), army (58093/2.33), four (73851/2.30), diverse (79511/2.29), people (204642/2.28), land (88587/2.13), against (336688/1.76), called (222669/1.71)

We have, as before, grouped the collocates, as far as was possible, into thematic groups, of which some could be seen as sub-groups of others. On this latter point, we clustered together the groups that share strongly negative connotations. These collectively constitute evidence that the concept 'Irish' had a very strong negative attitudinal component, as reflected in negative connotations across a number of words, that is to say, a strong negative semantic prosody (e.g. Louw, 1993). ${ }^{9}$ The groups are ordered according to the number of collocates in them.

\section{NEGATIVE CONNOTATIONS:}

Associated GROUPS: Scots, Irish, Picts, Scottish, Ireland, English (but suspect negative English groups such as rebels)

UNCIVILISED: wild, savage

HosTILE: enemies, against

UNGOVERNABLE: rebels

NOTORIOUS(?): mere 
This is the final pre-publication version of: Culpeper, Jonathan and Findlay, Alison (2020) National identities in the context of Shakespeare's Henry V: Exploring contemporary understandings through collocations. Language and Literature 29(3): 203-222. It may contain minor errors or infelicities.

WAR: wars, thousand (usually in reference to army numbers, but sometimes the number slain), army, four (usually in reference to army numbers, e.g. 'four thousand') CONQUEST AND SUPPRESSION: slue, slain, hundred (in reference to numbers slain)

NOBILITY: lords, gentleman

LANGUAGE: tongue, called

POLITICAL POWER: nation, people

In spite of this predominantly negative set of associations, it is perhaps surprising that the top collocate for Irish is rug. In Thomas Eliot's French language tutor Ortho-epica Gallia (1593: 115), it is referred to casually in both French and in English as an everyday item in the draper's shop: 'Show me a fair scarlet, a welch frise, a good Irish rug'. The word 'good' does not occur in the French 'un revesche d'Irlandres,' but in English it suggests the economic value of Ireland to English readers and spectators (Eliot, 1593: 1v-2). An account of the rug as part of the complex cultural fabric interweaving Irish industry, English exploitation and the potential danger therein, is found in Holinshed's Chronicles (1577). Holinshed (1577: 13) tells that in Waterford 'yoong and old are wholie addicted to thriuing,' the women as producers and the men 'commonlie to traffike'. He remarks that as well as distilling 'the best Aqua vitae, so they spin the choisest rug in Ireland.' The rugs are valued for their warmth, though the narrator's acquaintance, wearing 'one of these Waterford rugs' in London in the frost, was set upon by dogs. If they had not been partly chained and muzzled, 'he doubted not, but that he should haue béene well tugd in this Irish rug'. As a result, he vows 'neuer to see beare baiting in anie such wéed'. The point of this anecdote is vague though it may refer obliquely to the 'rug-headed kerns' (Richard II 2.1.56) or Irish soldiers who were famous for their distinctive bushy hairstyles hanging down over their eyes (see Edelman 2000: 197). It is clear that such sartorial border-crossing is dangerous. The Irish rug marks the wearer out as a target for violent mutilation and consumption by native (savage?) English dogs or bears. Is Holinshed making an oblique comment on the risks or brutality of colonial economic power? Whatever the nuances, he concludes his account with a striking contrast to the London scene:

The citie of Waterford hath continued to the crowne of England so loiall, that it is not found registred since the conquest to haue beene distained with the smallest spot, or dusked with the least freckle of treason.

(Holinshed, Chronicles 1577: 13)

It is true that Irish shares two of the collocate groups, NOBILITY and POLITICAL POWER, that we saw amongst those for Scots/Scottish. But note that these groups are thinly populated; they have far less weight compared with Scots/Scottish. Theirs is not a dynasty to be simultaneously respected and feared. The majority of collocates for Irish are, in fact, distinctly negative, but, as we will describe in the remainder of this section, those attitudes are driven by a specific, complex conception of the very nature of the Irish themselves.

Rebels, wild and savage are almost always used either to refer directly to the Irish themselves or act as an attributive adjective of the term Irish. None of the other 'nationalities' have terms directly evaluating them in this way. The AssocIATED 
This is the final pre-publication version of: Culpeper, Jonathan and Findlay, Alison (2020) National identities in the context of Shakespeare's Henry V: Exploring contemporary understandings through collocations. Language and Literature 29(3): 203-222. It may contain minor errors or infelicities.

GROUPS Scots, Irish, Picts, Scottish, Ireland, and especially the inclusion of the Irish, are unsurprising, given what we have already ascertained about opinions of the Scots helping the Irish rebels. As Highley (1997: 68) points out, William Harrison claimed that 'The Scots and the Irish are all one people' drawing their identity from a mixture of Scithian and Spanish blood, and John Dymmock remarked that in Ireland 'the wilde Scottes' lived alongside 'English Irish, meer Irish, [and] degenerate English'. This final phrase, 'degenerate English' points to a characteristic of the ASSOCIATED GROUPS collocate English. Scrutiny of examples reveals that it mostly modifies the word rebels. As the Holinshed example above shows, barbaric behaviour may be uncomfortably close to home. Sir Walter Ralegh's account of Englishmen rebelling to join the Spanish Catholics in the Azores in 1591, published in Hakluyt's Principal Navigations in 1599, showed that Irish rebellion might easily contaminate Englishmen. Ralegh asserts (Hakluyt 1599: 173) that one 'Morice Fitz Iohn' part of family of the southern Irish rebel, the Earl of Desmond, 'was sent to the English from shippe to shippe, to perswade them to serue the King of Spaine' for reward. It is, of course, such French 'crowns' that persuade the degenerate English nobles Grey, Scrope and Cambridge (the ancestor of the Earl of Essex) to betray their king in Henry $V$. Henry refers to them as 'English monsters' (1.2.82), singling out Scope as an 'ingrateful, savage and inhuman creature' (1.2.92). Ralegh's report, amidst the Irish troubles, would have advertised a common fear that any Englishman, even Essex himself, might be persuaded to 'be unnatural to his own Country that bred him; to his parents that begat him, and rebellious to his true Prince, to whose obedience he is bound by oath, by nature, and by Religion' (Hakluyt, 1599: 174).

Since English identity was, as Murphy (1996: 39) observes, 'predicated upon a process of contradistinguishing a set of English characteristics from a stereotype of the "wild Irish",' it is not surprising that the word mere (meaning a pure or unmixed race $O E D$, adj.2 1c or II,4 'absolute' ) is an prominent collocate of 'Irish' in the EEBO data. Richard Stanyhurst's description of Ireland in the Second Volume of the Chronicles was very careful to distinguish the 'wylde Irish' or 'meere Irish' from the 'inhabitants of the English pale' who live in Ireland and keep the 'ancient customes and dispositions of their progenitors, the English and Welsh men' and so are 'as mortallie behated of the Irish, as those that are borne in England' (Holinshed 1587: 45). In contrast to the pejorative meaning of mere as 'insignificant' (OED adj.II,5), it is likely that collocation of mere with the Irish at this time drew on its Old English meaning of 'infamous' or 'notorious', as in Beowulf, where the monster Grendel is a 'mære mearcstapa,' a notorious march-stepper, meaning a riever, or border raider (OED adj.1). It is this frighteningly alien connotation that characterised the 'meere' Irish kerns or warriors who supposedly lived 'wylde' in the woods and marshes, fought 'naked' (without armour), were 'shag-haired' and 'crafty' (2Henry VI 3.1.367-9; Edelman, 2000: 1867). ${ }^{10}$

Paradoxically, but perhaps even more disturbingly, the Irish were examples of hybridity which confounded the 'simple binary colonial stereotype' which the English used to define themselves and their neighbours, and so were profoundly disturbing (Murphy, 1996: 39). Hugh O'Neill, the rebel Earl of Tyrone, was himself an example of such hybridity since he had been born in Ireland of Gaelic parentage, then fostered by an Anglo-Irish family, serving the English in the 1570s before turning to his own independent interests and those of Ireland (Murphy, 1996: 39-41). Captain Thomas Lee, Captain General of the Irish Kern, supposedly recruited to defend the Queen's English 
This is the final pre-publication version of: Culpeper, Jonathan and Findlay, Alison (2020) National identities in the context of Shakespeare's Henry V: Exploring contemporary understandings through collocations. Language and Literature 29(3): 203-222. It may contain minor errors or infelicities.

interests in Ireland, was an equally ambiguous figure. His hybridity is represented in a painting by Gheeraerts in which he appears to have 'gone native': with naked legs and feet below his doublet, he carries a native spear and stands in front of a wild, dark forest and mountains (Highley, 1997: 92-3). Given all these multiple associations with 'Irish', early modern spectators would have brought a very complex set of understandings to the figure of MacMorris in Henry $V$. Rather than being rhetorical, his question 'What ish my nation?' was directed very immediately to each of them.

\section{The collocates of Welsh}

The collocates of Welsh are (the numbers in brackets indicate the raw frequency of the collocate followed by its LogRatio value):

Britons (1203/7.78), tamed (1329/7.49), rebelled (2076/7.48), marches (2148/7.21), ${ }^{11}$ rebel (4405/7.04), Wales (6380/6.05), Englishmen (6867/6.03), subdued (7045/5.90), Irish (5312/5.77), rebellion (9382/5.49), vanquished (7808/4.92), overthrown (8746/4.91), Scots (13048/4.82), fought (11330/4.39), language (12089/4.12), agree (19074/3.92), slain (44055/3.90), wild (17837/3.88), English (50622/3.76), join (15631/3.75), named (34496/3.61), tongue (37141/3.59), wars (33107/3.48), borne (50908/3.44), against (336688/3.19), number (84514/3.07), victory (28393/2.89), commonly (28648/2.87), call (85831/2.69), called (222669/2.59), took (75781/2.56), thousand (67948/2.54), coming (60124/2.39), amongst (65801/2.38), went (83398/2.14), taken (122299/2.10), power (152415/1.92), men (494274/1.81), king $(386345 / 1.25)$

We grouped the collocates, as far as was possible, into the following thematic groups (ordered according to the number of collocates in them):

WAR: fought, wars, against (usually followed by 'the Welshmen'), number (usually in reference to army numbers), victory, thousand, went (usually followed by 'against the Welshmen), taken

CONQUEST AND SUPPRESSION: tamed, rebelled (usually followed by a statement that they were then 'vanquished' or 'subdued'), subdued, vanquished, overthrown, slain, agree (usually the Welsh being pressured to agree), LANGUAGE: language, tongue, commonly (e.g. 'commonly called'), call, called ASSOCIATED GROUPS: Englishmen, Irish, Scots, UNGOVERNABLE: rebel, rebellion

UNCIVILISED: wild

POWERFUL: power

Unlike the collocates for Irish, those for Welsh, whilst including potentially dangerous elements - wild, rebel and rebellion forming the UNCIVILISED and UNGOVERNABLE groups - give the overall impression of danger past, as can be seen in the CONQUEST AND SUPPRESSION GROUP: rebellion subdued, vanquished, overthrown, slain and wildness tamed. Talk about the Welsh now is often, as one can see from the well-stocked LANGUAGE group, concerned with their curious Welsh language or tongue, and how it differs from English. Such associations fit naturally with Wales's Tudor history, since, after it was conquered by Edward I, it was 'annexed and united' to 
This is the final pre-publication version of: Culpeper, Jonathan and Findlay, Alison (2020) National identities in the context of Shakespeare's Henry V: Exploring contemporary understandings through collocations. Language and Literature 29(3): 203-222. It may contain minor errors or infelicities.

the English crown 'as a Member of the same Body' by an Act of Union in 1536 (Highley, 1997: 69). The ambiguous identity of Wales as somewhat wild, powerful, and yet tamed, are matched well in the Welsh captain Fluellen in Henry V. Although Fluellen is experienced and passionate about the 'disciplines of the wars' from classical traditions, he is also proud to claim Henry $\mathrm{V}$ as his countryman (4.7.103-7). The same qualities of alliance and accommodation are associated with Wales as a model for peace in a time of uncertainty towards the end of Elizabeth's reign. Even the zealous Jesuit William Allen (1595: unnumbered) could praise the compromise represented by Wales:

[...] in the welsh also towards the English, who are a different people and of different language, and yet are they governed peaceably by the English, \& the English again do account them for their country men as may appear by that, when king Henry the seventh, came to be king of England, I do not find, any resistance made against him by the English, for that respect that he was of that nation, as evidently he was by his fathers side, that was of the Tidders of Wales, so as this point also who be straingers and who be not, seems to be a thing that depends much of the opinion and affection of each people \& nation, the one towards the other.

Welsh accommodation is directly linked with a Tudor succession of peace, as Henry VII landed at the Welsh port of Milford Haven, to put an end to the Wars of the Roses. In the peace after Agincourt, Fluellen likewise accepts Henry V's claim of national brotherhood 'For I am Welsh, you know, good countryman' (IV.vii). In a much more supportive model of consanguinity Fluellen asserts 'All the water in the Wye cannot wash your majesty's Welsh blood out of your body' (IV.vii). Moreover, Fluellen celebrates the acceptance of a stranger, telling Henry V 'I am your majesty's countryman. I care not who know it, I will confess it to the world' (IV.vii). Borders and thoughts of subjection evaporate in a warmth of incorporation. The Welshman Fluellen enacts one of his nation's key collocates: agree.

The wildness and power which characterized Glendywr in Henry IV Part I, and demonstrated the potential for Wales to lapse back into rebellious 'otherness' like Ireland, has been 'tamed' or incorporated into England in Henry V. Nevertheless, as Highley (1997: 156) points out, there was great resistance amongst the Welsh to serving in Ireland at the time of Tyrone's rebellion. In addition to hiding from the musters and suffering imprisonment, in one case, a pair of brothers explicitly stated that in no circumstances would they fight for the Queen. In Thomas Churchyard's The Worthiness of Wales (1587: unnumbered), Wales becomes an idealistic homely but fantastic utopia:

Where shall we finde, such dealing now adaies?

Where is such chéere, so cheape and chaunge of fare?

Ride North and South, and search all beaten waies,

From Barwick bounds, to Venice if you dare,

And finde the like, that I in Wales haue found,

And I shall be, your slaue and bondman bound.

If Wales be thus, as tryall well shall proue,

Take Wales goodwill, and giue them neighbours loue. 
This is the final pre-publication version of: Culpeper, Jonathan and Findlay, Alison (2020) National identities in the context of Shakespeare's Henry V: Exploring contemporary understandings through collocations. Language and Literature 29(3): 203-222. It may contain minor errors or infelicities.

Given widespread reluctance amongst the Welsh to serve in Ireland, Fluellen's often homely, warm support of his king in Henry $V$ is a wishful example of the 'neighbour's love' that creates harmonious nationhood.

\section{A glance at the collocates of English}

It is instructive to compare briefly the Celtic results with that of English as a means of throwing those results into relief. The collocates of English are:

translated (9774/6.08), bible (5010/5.90), pale (5143/5.84), Danes (5193/5.49), Scots (13048/5.32), nation (22656/5.25), Latin (23266/5.01), translation (7287/4.86), tongue (37141/4.85),nobility (13766/4.01), writers (14822/4.00), French (42300/3.97), army (58093/3.71), ships (29704/3.51), camp (20110/3.47), history (20901/3.25), books (30167/3.03), men (494274/2.81), subjects (34559/2.59), slain (44055/2.50), Lords (56233/2.39), soldiers (51326/2.19), borne (50908/2.15), service (61558/1.97), diverse (79511/1.78), hands (91756/1.74), certain (129291/1.67), taken (12299/1.65), against (336688/1.61), hundred (72416/1.58), number (84514/1.46), enemies (75243/1.46), speak (96391/1.30), called (222669/1.25), people (204642/1.25), call (85831/1.21), old (112211/1.16), new (104418/1.02), set (165599/1.02), came (153499/1.02), part (208312/0.95), sent (108246/0.92), Church (279219/0.82), word (192829/0.81), say (280205/0.59), well (304786/0.56), man $(522546 / 0.44)$

English clearly has a broader sphere of use. There are two groups here, which, though small, are not represented in the Celtic results. One concerns RELIGION (bible, Latin, Church), and the other LITERARY ACTIVITY (writers, books). There is a set of ASSOCIATED GROUPS - Danes, Scots and French - but the membership, though superficially similar, is in fact different from the Celtic results. In the case of Danes, they are operating together with the English as allies, not enemies. With Scots, sometimes they are allies or equals, but other times they are attacking each other. As for French, a substantial pattern relates to the French language, often concerning matters of translation. There is, however, also a strong pattern representing an antagonistic, combative relationship between the English and French. As with Irish and Welsh, there is a group to do with LANGUAGE. However, this time it is dominated by a set to do with translation into English (translated, translation, tongue, called, call, word). Finally, as with all Celtic results, there is a WAR set (e.g. army, ships, camp, soldiers, taken).

\section{Conclusion}

This paper has demonstrated how analysing the collocates of words reveals the seams (or indeed semes ${ }^{12}$ ) of meaning that colour a target word. The words Scots/Scottish, Irish and Welsh furnish us with a robust, empirical way of tapping into how people in early modern English were talking about those identities and thus into their attitudes towards them. In each case, what was revealed is complex and nuanced. A central aspect of constructions of the Scots/Scottish identity revolves around borders (it is the only Celtic group to have such a collocate), the site of a tension between hostile invasion and deadly expulsion. Yet, whilst associated with negative actions and consorting with suspect groups, the French and Irish, collocates point towards the Scots' distinguished heritage, as recorded in histories and symbolized by illustrious 
This is the final pre-publication version of: Culpeper, Jonathan and Findlay, Alison (2020) National identities in the context of Shakespeare's Henry V: Exploring contemporary understandings through collocations. Language and Literature 29(3): 203-222. It may contain minor errors or infelicities.

monarchs. They represented a powerful threat. One might guess that constructions of Irish identity would be wholly negative, but we revealed a strongly positive strand in the context of the Irish rug, though we noted that even here there was a possible undercurrent of danger. What is distinctive about the negative attitudes displayed in the Irish collocates is that negative terms, notably rebels, wild and savage, directly describe the Irish. We dwelt on the collocate mere. A group of the Irish, the archetype being Irish kerns or warriors, are thought of in racial terms: mere not only alludes to racial purity but connects that to a sense of notoriety - these Irish, like the terrifying Grendel of Beowulf, are an alien people, wild and savage, not part of civilisation. However, not all Irish are so: as the groups of collocates relating to nobility and political power suggest. Yet, for those who were not "mere Irish", they were liable to be seen as hybrids, part wild, part civilised, defying easy categorisation. This is where MacMorris stands, as indeed the etymology of his own name hints; he is the man who represents the dilemma of Irish nationhood. Finally, constructions of Welsh identity, whilst sharing the dangerous elements indicated in the collocates wild and rebel with the Irish, place such aspects in the past - they are now tamed. The Welsh are now an in-group about which one comments on the curiosities of their language. Having said that, the wildness of the Welsh is tamed but not gone; relapse is still a possibility.

Highley (1997: 150) argues that Henry $V$ is 'an open site of struggles between conflicting impulses and explanations about Ireland, the Tyrone rebellion and the Desmond rebellion which preceded it.' But such tensions are not restricted to the Irish. Struggles in bringing four nations together as one are played out discursively, we would argue, through the linguistic battles between the four captains. This is not just in what they do and say to each other, to the king and to their fellow soldiers, but crucially in the ways their words and actions exemplify the racial stereotypes associated with their nations - the social schemata feeding processes of characterisation - that early modern spectators would have recognised. Far from being what Simpson called a 'union of four nations' whose membership of the commonwealth is 'unhindered by 'the touchiness of a separatist nationalism', the Captains are distinctive spokesmen for their countries. Interaction between them is the 'touchiness' or friction of difference that could always spark an explosion. John Harvey's pamphlet $A$ discoursiue probleme concerning prophesies how far they are to be valued, or credited (1588) lamented the state of the nation irrevocably divided by difference:

England, thy country betrays thee, as each other hates thee: The Scot incrocheth: the Frenchman gapes for a vantage: Wales threatens kindness: wild Irish lurks in ambush: Behold thy captains dispatched all on a sudden: And Ruin hudled up, when thou think lest of a mischief: Peace fostered for a time, shall finally prove to be fained Which breaking unawares, shall bring on greeuousser horror.

Henry $V$ amply advertises such tensions beneath the show of alliance that the four Captains present. The play is, as Highley argues, 'an arena in which the ideology of benevolent colonialism begins to unravel' (1997:150) even while the Captains appear to be defending the English cause.

Of course, all methods have their limitations. Our evidence for early modern conceptions of the Scottish, Irish and Welsh is limited to what survived from Shakespeare's time. This thus excludes spoken language, the bulk of one's linguistic output, and also written ephemera. Should we conclude, therefore, that the conceptions 
This is the final pre-publication version of: Culpeper, Jonathan and Findlay, Alison (2020) National identities in the context of Shakespeare's Henry V: Exploring contemporary understandings through collocations. Language and Literature 29(3): 203-222. It may contain minor errors or infelicities.

we have articulated would only pertain to the few relatively literate people of the time? Whilst it may well be that our articulations better reflect that group of people, we do not think that they are irrelevant to the wider population. Importantly, it should be remembered that a significant proportion of our written material was designed for public consumption. Play-texts are a good example of this, as they were performed to large audiences of widely varying social rank. We should also remember that literate people did not exist in isolation from non-literate people and would have exposed them to their views.

\section{Funding}

The research presented in this article was supported by the UK's Arts and Humanities Research Council (AHRC), grant reference AH/N002415/1.

\section{Declaration of conflicting interests}

The authors declared no potential conflicts of interest with respect to the research, authorship, and/or publication of this article.

\section{References}

Allen W (1595) A Conference About the Next Succession to the Crowne of Ingland. London. (STC 19398).

Culpeper J (2001) Language and Characterisation: People in Plays and other Texts. Harlow: (Longman) Pearson Education.

Baker D (2004) Stands Scotland where it did? Shakespeare on the march. In: Maley W and Murphy A (eds) Shakespeare and Scotland. Manchester: Manchester University Press, pp. 20-36.

Baker D, Palmer P and Maley W (2018) 'What ish my network?' Introducing MACMORRIS: Digitising cultural activity and collaborative networks in early modern Ireland. Literature Compass 15(2): e12496. DOI:10.1111/lic3.12496.

Baker P, Gabrielatos C and McEnery T (2013) Discourse Analysis and Media Attitudes: The Representation of Islam in the British Press. Cambridge: Cambridge University Press.

Blake NF (1983) Shakespeare's Language: An Introduction. London: MacMillan.

Churchyard T (1587) The Worthiness of Wales. (STC 5261).

Connolly SJ (2007) Contested Island: Ireland 1460-1630. Oxford: Oxford University Press.

Dollimore J and Sinfield A (1985) History and Ideology: the instance of Henry $V$. In: Drakakis J (ed.) Alternative Shakespeares. London and New York: Routledge, pp. 206-27.

Dowden E (1875) Shakespeare's Mind and Art. London: Henry King and Co.

Dutton R (2005) 'Methinks the truth should live from age to age'. The Dating and Contexts of Henry V. Huntington Library Quarterly 68(1-2): 173-204.

Dutton R (2018) Shakespeare: Court Dramatist. Oxford: Oxford University Press.

Edelman C (2000) Shakespeare's Military Language. London: Athlone (Bloomsbury).

Edwards P (1979) Threshold of a Nation: A Study in English and Irish Drama. Cambridge: Cambridge University Press.

Eliot J (1593) Ortho-epia Gallica: Eliots fruits for French... Pend for the practise, pleasure and profi all English gentlemen. London: p1v-p2. (STC 7574). 
This is the final pre-publication version of: Culpeper, Jonathan and Findlay, Alison (2020) National identities in the context of Shakespeare's Henry V: Exploring contemporary understandings through collocations. Language and Literature 29(3): 203-222. It may contain minor errors or infelicities.

Firth JR (1957) A synopsis of linguistic theory, 1930-1955. In: Studies in Linguistic Analysis (Special volume of the Philological Society). Oxford: Basil Blackwell, pp.1-32.

Gould G (1919) A New Reading of Henry V. English Review (29): 42-55.

Hakluyt R (1599) The principal nauigations, voyages, traffiques and discoueries of the English nation made by sea or ouer-land. (STC 12626a).

Hammer PEJ (2008) Robert Devereux, Second Earl of Essex. Oxford Dictionary of National Biography. Available at: https://www-oxforddnbcom.ezproxy.lancs.ac.uk/view/10.1093/ref:odnb/9780198614128.001.0001/odnb -9780198614128-e-7565. (accessed 11 October 2019)

Hardie A (2012) CQPweb - combining power, flexibility and usability in a corpus analysis tool. International Journal of Corpus Linguistics 17 (3): 380-409.

Highley C (1997) Shakespeare, Spenser and the Crisis in Ireland. Cambridge: Cambridge University Press.

Holderness G (1991) 'What Ish My Nation?' Shakespeare and National Identities. Textual Practice 5(1): 74-95. Reprinted in Kamps I (1995) (eds) Materialist Shakespeares. London: Verso, pp. 218-238.

Holinshed R (1577) The firste [laste] volume of the chronicles of England, Scotlande, and Irelande conteyning the description and chronicles of England, from the first inhabiting vnto the conquest [...]. (STC 13568b).

Holinshed R (1587) The first and second volumes of Chronicles comprising 1 The Description and historie of England, 2 The description of historie of Ireland [...]. (STC 13569).

Hopkins L (2004) Welshness in Shakespeare's English Histories. In: Hoenselaars T (ed.) Shakespeare's History Plays: Performance, Translation and Adaptation in Britain and Abroad. Cambridge: Cambridge University Press, pp. 60-74.

Ivic C (1999) Our inland: Shakespeare's Henry V and the Celtic Fringe. Ariel: A Review of International Literature 30(1): 85-103.

Kasof J (1993) Sex bias in the naming of stimulus persons. Psychological Bulletin 113(1):140-163.

Knowles G (1997) A Cultural History of the English Language. London: Arnold.

Louw B (1993) Irony in the text or insincerity in the writer? The diagnostic potential of semantic prosodies. In: Baker M, Francis G and Tognini-Bonelli E (eds) Text and Technology: In Honour of John Sinclair. Amsterdam: John Benjamins, pp. 157-176.

Maley W (2007) A Thing Most Brutish: Depicting Shakespeare's Multi-Nation State Shakespeare 3(1): 79-101.

Murphy S (2019) Designing a genre classification scheme for Early English Books Online 1560-1640. ICAME Journal 19: 59-82.

Murphy A (1996) Shakespeare's Irish History Literature and History 5 (1): 38-59

Murphy A (2015) Shakespeare's Irish lives: The politics of biography. In: Holland P (ed.) Shakespeare Survey. Cambridge: Cambridge University Press, pp.267-281. doi:10.1017/CBO9781316258736.021

Neill M (1994) Broken English and Broken Irish: Nation, Language and the Optic of Power in Shakespeare's Histories. Shakespeare Quarterly 45(1): 1-32.

O'Neill S (2016) Beyond MacMorris: Shakespeare, Ireland and Critical Contexts. In: Loughnane R (eds) Celtic Shakespeare: The Bard and the Borderers. Abingdon, UK and New York: Routledge, pp. 245-258. 
This is the final pre-publication version of: Culpeper, Jonathan and Findlay, Alison (2020) National identities in the context of Shakespeare's Henry V: Exploring contemporary understandings through collocations. Language and Literature 29(3): 203-222. It may contain minor errors or infelicities.

Ocland C, trans. Sharrock J, (1585) The valiant actes and victorious battailes of the English nation. London, fol. G1r. (STC 18777).

Partington A (1998) Patterns and Meanings. Amsterdam: John Benjamins.

Pasupathi VC (2013) The Quality of Mercenaries: Contextualizing Shakespeare's Scots in 1 Henry IV and Henry V. In: Maley $\mathrm{W}$ and Loughnane R (eds) Celtic Shakespeare. London: Routledge, pp. 35-60.

Puttenham G (1598) The Arte of English Poesie. London: Richard Field. (STC 20519.5). Rabkin N (1977) Rabbits, Ducks, and Henry V. Shakespeare Quarterly 28(3): 279-296.

Shapiro J (2006) 1599: A Year in the Life of William Shakespeare. London: Faber and Faber.

Stockwell P and Mahlberg M (2015). Mind-modelling with corpus stylistics in David Copperfield. Language and Literature 24(2): 129-147.

Taylor G (1982) (eds) Henry V. Oxford: Oxford University Press.

Whitsitt S (2005) A critique of the concept of semantic prosody. International Journal of Corpus Linguistics 10(3): 283-305.

\section{Bionotes}

Jonathan Culpeper is Professor of English Language and Linguistics. His publications include Language and Characterisation in Plays and Other Texts (2001) and Early Modern English Dialogues: Spoken Interaction as Writing (2010; with Merja Kytö). He leads the AHRC-funded Encyclopedia of Shakespeare's Language project.

Alison Findlay is Professor of Renaissance Drama. She is Chair of the British Shakespeare Association. Her publications include Women in Shakespeare (2013) and Shakespeare in Greece (2017). She is a volume editor on the Encyclopedia of Shakespeare's Language project.

\footnotetext{
${ }^{1}$ Richard Dutton, however, argues that these references did not exist in Q1 the earliest version of the play but were added progressively, the play's reference to the victorious 'General' possibly referring to Charles Blount who won the Battle of Kinsale over the Irish in 1601 (Dutton, 2018:182). See also Richard Dutton's earlier article (2005) on Charles Blount, Lord Mountjoy.

${ }^{2}$ https://www.maynoothuniversity.ie/arts-and-humanities-institute/hosted-research-projects/macmorris

3 A substantial bibliography of scholars who have worked on Shakespeare's language can be found here: http://wp.lancs.ac.uk/shakespearelang/files/2016/06/Shakespeare-Encyclopaedia-Bibliography.pdf.

${ }^{4}$ See http://ucrel.lancs.ac.uk/vard/about

${ }^{5}$ Knowles (1997: 130) suggests, without supplying specific detail, that the particular variant Inglis referred to the English of Scotland. However, whilst it is true that one can detect a pattern whereby Inglis tends to be used in texts written in Scottish English, those uses do not always refer to the English of Scotland. Moreover, many more uses appear in the period of our data as simply a variant for English (in relation to England). Hence, we include it in our English search.

${ }^{6}$ There is no gold standard or rule for a minimum frequency, except that generally it is proportional to the number of results (this relationship can be seen in Table 1). We generated our minimum frequencies through trial and error, aiming to eliminate as many idiosyncratic results (i.e. low frequency, and / or narrowly dispersed) as possible, without sacrificing 'good' results. Such a measure does not guarantee perfection, which is why, as discussed, we also manually filtered our results.

${ }^{7}$ LogRatio was devised by Andrew Hardie, the first and main account of which is in his blog: http://cass.lancs.ac.uk/log-ratio-an-informal-introduction/

${ }^{8}$ The actis and constitutiounis of the realme of Scotland maid in Parliamentis haldin be the rycht excellent, hie and mychtie princeis kingis James the first, secund, thrid, feird, fyft, and in tyme of Marie
} 
This is the final pre-publication version of: Culpeper, Jonathan and Findlay, Alison (2020) National identities in the context of Shakespeare's Henry V: Exploring contemporary understandings through collocations. Language and Literature 29(3): 203-222. It may contain minor errors or infelicities.

now quene of Scottis, viseit, correctid, and extractit furth of the registers by the Lordis Depute be hir Maiestieis speciall commissioun thairto. Anno Do. 1566, fol. Ziiir-v.

${ }^{9}$ From the beginning, the concept of semantic prosody was inadequately specified in Louw (1993), as Whitsitt's (2005) insightful critique makes clear. Consequently, various re-interpretations of the notion have evolved. The notion of semantic prosody articulated in this paper - a pattern of semantically/pragmatically similar connotations spread over a number of words - is closest to that of Partington (e.g. 1998).

${ }^{10}$ Ironically, the pejorative, colonial resonance of the word mere continued into the Victorian period via Shakespeare, in a review of Edward Dowden's (1875) Shakespeare's Mind and Art, headlined "Literary Intelligence' in the United Irishman, Issue 88, Volume 4 (3 November, 1900). Signed by Lugh, which is possibly a pseudonym, the piece praises Dowden as 'a blue-blooded Englishman, free from the slightest taint of Irish ancestry . . . honoured, some time ago, with the Sloper Award of Merit, in recognition of his eminent services as a spreader of civilisation amongst the mere Irish.' (p.7, as cited in Murphy 2015: 271). Alison Findlay thanks Andrew Murphy for this reference.

${ }^{11}$ Not a military term, but used to refer to the Welsh Marches - the area of land bordering Wales and England.

${ }^{12}$ From Greek sēma, ‘sign', a minimal distinctive unit of meaning. 